\title{
Submandibular Lymph Node
}

National Cancer Institute

\section{Source}

National Cancer Institute. Submandibular Lymph Node. NCI Thesaurus. Code C77650.

A lymph node located beneath the floor of the oral cavity. 